\title{
OPTIMUM PLANT POPULATION FOR MAIZE-BEAN INTERCROPPING SYSTEM IN THE BRAZILIAN SEMI-ARID REGION
}

\author{
Luiz Balbino Morgado ${ }^{*}$; Robert William Willey ${ }^{2}$ \\ ${ }^{1}$ Embrapa Semi-Árido, C.P. 23 - 56301-970 - Petrolina, PE - Brasil. \\ ${ }^{2}$ University of East Anglia, School of Development Studies, NR4 7TJ Norwich, United Kingdom (retired professor). \\ *Corresponding author <lmorgado@cpatsa.embrapa.br>
}

\begin{abstract}
Establishment of the ideal number of plant is a crucial point for obtaining maximum profits while cropping different species together. The main objective of the study was to investigate the effect of different plant populations of maize and beans, at two nitrogen levels, on the performance of the component crops. Two maize (20,000 and 40,000 plants ha $\left.{ }^{-1}\right)$ and three bean $(30,000 ; 60,000$ and 90,000 plants $\mathrm{ha}^{-1}$ ) populations were tested in a randomized complete block design with tree replicates. Grain yields of maize and beans were affected by intercropping and the effect was more detrimental to the legume mainly at the highest maize plant population. The application of nitrogen fertilizer to maize rows mitigated intercropping effect on maize at higher population $\left(40,000\right.$ plants $\left.\mathrm{ha}^{-1}\right)$ and, at lower maize plant population (20,000 plants $\left.\mathrm{ha}^{-1}\right)$, benefited the associated beans by increasing grain yields. Land Equivalent Ratio values for grain yields of maize and beans showed that intercropping compared to sole cropping is advantageous and best indices were obtained at a bean plant population of 60,000 plants ha $^{-1}$.
\end{abstract}

Key words: Zea mays, Phaseolus vulgaris, cropping system, plant density

\section{POPULAÇÃO ÓTIMA DE PLANTAS NO CONSÓRCIO MILHO-FEIJÃO NO SEMI-ÁRIDO BRASILEIRO}

\begin{abstract}
RESUMO: A definição do número de plantas por área é fundamental para a obtenção de ganhos quando diferentes espécies são plantadas juntas. O principal objetivo do estudo foi investigar o efeito de diferentes populações de plantas, sob dois níveis de nitrogênio, no desempenho do milho e do feijão em plantio consorciado Duas populações de milho (20.000 e 40.000 plantas ha $\left.^{-1}\right)$ e três de feijão (30.000; 60.000 e 90.000 plantas ha $^{-1}$ ) foram testadas em um delineamento de blocos ao acaso com três repetições. As produções de grãos de milho e feijão foram afetadas pelo consórcio, sendo o efeito mais prejudicial para a leguminosa. A aplicação de fertilizante nitrogenado diminuiu o efeito competitivo do consórcio para o milho na maior população (40.000 plantas ha ${ }^{-1}$ ), e, na menor população (20.000 plantas ha ${ }^{-1}$ ), favoreceu o feijão com o aumento de sua produção de grãos. Os índices para Uso Eficiente da Terra para produção de grãos de milho e feijão revelaram que o consórcio é mais vantajoso que o plantio isolado das culturas, com os melhores valores com a população de plantas de feijão correspondente a 60.000 plantas $\mathrm{ha}^{-1}$.

Palavras-chave: Zea mays, Phaseolus vulgaris, sistema de plantio, densidade de plantas
\end{abstract}

\section{INTRODUCTION}

The optimum plant population for maize in sole cropping is 40,000 plants $\mathrm{ha}^{-1}$ under rainfed conditions in the semi-arid Northeast Brazil. Half of this population may be used in intercropping studies in row arrangements of one row of maize to two or three rows of beans (Rao \& Morgado, 1984). Lima \& Lopes (1981), in a plant population and spatial arrangement study on maize-bean intercropping, reported that intercropping was more advantageous than sole cropping and the highest Land Equivalent Ratios - LERs were obtained in the spatial arrangement of one row of maize to two or three rows of beans.

In an intercropping study under temperate climate condition, when maize at a constant plant population was intercropped with three bean plant populations, Morgado \& Willey (2003) showed that competitive effect of intercrop beans on maize yields was high at higher plant populations.

Morpho-physiological differences and agronomic factors such as the proportion of crops in the mixture and fertilizer application regulate competition between component crops for growth-limiting factors 
(Trenbath, 1986; Russell \& Caldwell, 1989). Greater total uptake of nutrients and other growth factors by the component crops in the intercropping is the primary cause of obtaining intercropping advantage (Willey, 1979; Chowdhury \& Rosario, 1994). In a maize-cowpea intercropping Ofori \& Stern (1987) found a negative interaction with the applied nitrogen and cowpea plant density. Intercropping research studies involving a cereal and a legume in the Brazilian Northeast have not considered the combined effect of fertilizer application and plant population variation (Lima \& Lopes, 1981; Mafra et al., 1979; Faris et al., 1983; Cardoso et al., 1994; Morgado, 2006).

In order to study the effects of plant population, at two nitrogen levels, on plant growth and yields of maize-bean intercropping an experiment was carried out in the semi-arid condition of the Brazilian Northeast.

\section{MATERIAL AND METHODS}

The trial was set up at Petrolina-Pe, Brazil $\left(09^{\circ} 09^{\prime} \mathrm{S}, 40^{\circ} 22^{\prime} \mathrm{W}\right.$, Altitude: $\left.365.5 \mathrm{~m}\right)$, in 1990. The soil was a Plinthic Haplustult, with $0.5 \mathrm{~g} \mathrm{~kg}^{-1}$ of organic $\mathrm{N}, 4.9 \mathrm{mmol}_{\mathrm{c}} \mathrm{dm}^{-3} \mathrm{~K}, 49.0 \mathrm{mg} \mathrm{dm}^{-3} \mathrm{P}, 24.0$ mmol $\mathrm{dm}^{-3} \mathrm{Ca}, 11.0 \mathrm{mmol}_{\mathrm{c}} \mathrm{dm}^{-3} \mathrm{Mg}$ and a $\mathrm{pH}$, in $\mathrm{H}_{2} \mathrm{O}$ (soil:water ratio 1:2.5), of 6.6. The climate is classified as BSwh', according to Köeppen, and annual average rainfall is $567.0 \mathrm{~mm}$. The amount of rainfall recorded during the growing season (February $01-$ May 31) was $105.2 \mathrm{~mm}$, considered low for that time of the year. Sprinkler irrigation was used when necessary at 10 days intervals to avoid soil water deficit.
Two plant populations $\left(20,000\right.$ plants $\mathrm{ha}^{-1}-$ M1; 40,000 plants $\mathrm{ha}^{-1}-$ M2) were used for intercropped maize and three proportions of sole cropping $\left(30-\mathrm{B} 1,60-\mathrm{B} 2\right.$ and 90,000 plants ha $\left.{ }^{-1}-\mathrm{B} 3\right)$ were used for intercropped beans. The three bean plant populations were interplanted with the two maize plant populations in an additive model, resulting in three row arrangements: i) one row of maize to one row of beans $(1: 1)$; ii) one row of maize to two rows of beans (1:2); iii) one row of maize to three rows of beans (1:3) (Figure 1). Sole treatments were included to compare the performance of intercropping related to sole cropping: maize at the highest plant population of intercropping system $\left(40,000\right.$ plants $\left.\mathrm{ha}^{-1}\right)$ and beans at 120,000 plants ha ${ }^{-1}$. A constant row spacing of $0.6 \mathrm{~m}$ was used for maize in sole and intercropping systems. Variation in plant population of intercropped maize was obtained by varying within row. Sole beans were sown on $0.3 \mathrm{~m}$ row spacing. Row spacing for intercropped beans varied with bean population, with plants being closer to maize rows as bean population increased. All plots were $30 \mathrm{~m}^{2}(3 \mathrm{~m} \times 10 \mathrm{~m})$.

A basal dose of phosphorus and potassium, corresponding to $80 \mathrm{~kg} \mathrm{P}_{2} \mathrm{O}_{5} \mathrm{ha}^{-1}$ and $40 \mathrm{~kg} \mathrm{~K}_{2} \mathrm{O} \mathrm{ha}^{-1}$, was uniformly broadcast before planting. Maize variety CMS 28 and bean variety HF 465 were sown by hand simultaneously at a high seed density, being thinned for the planned plant populations 23 days after sowing (DAS). Sole and intercropped maize were submitted to two soil nitrogen levels: $0 \mathrm{~kg} \mathrm{ha}^{-1}-\mathrm{N} 1$ and $30 \mathrm{~kg} \mathrm{ha}^{-1}-\mathrm{N} 2$. The nitrogen was applied to maize rows as Urea $(45 \% \mathrm{~N})$ in two split, at 30 and 40 DAS. Starting from 23 DAS, at intervals of ten days, three

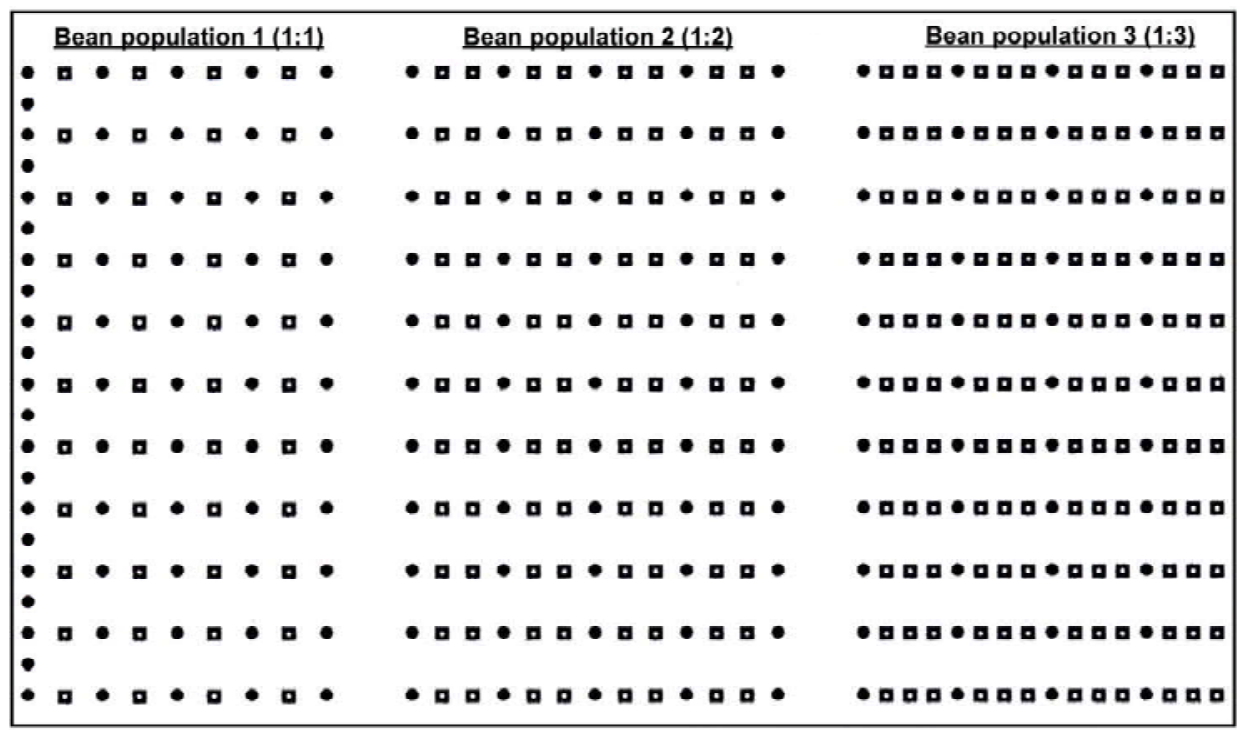

Figure 1 - Row arrangement of maize $(\bullet)$ and beans $(\mathbf{\square})$ in intercropping system. 
plants each of maize and beans were cut at soil level and dried at $70^{\circ} \mathrm{C}$ for dry matter determination.

At harvest time one meter at each end of all plots was discarded as border. Outsider rows of sole and intercropped maize plots were discarded and three $6 \mathrm{~m}$ long middle rows were harvested. Harvest rows of intercropped beans were $6.4 \mathrm{~m}$ long and plants of all rows were harvested. Three $5.4 \mathrm{~m}$ long middle rows were harvested in sole cropped bean plots. Beans were harvested 78 DAS as dry seeds, and number and weight of pod per plant, seed weight per plot and individual pod weight were determined. Maize was harvested 115 DAS and plants were cut at soil level; weight and number of cobs and weight of grain per plot were determined. Three plants with cobs of all plots were dried at $70^{\circ} \mathrm{C}$ for dry matter determination.

\section{Data Analysis}

The experimental design was a randomized complete block with three replicates. The treatments consisted of a factorial combination of two maize plant populations; three bean plant populations and two levels of nitrogen fertilizer, corresponding to 12 intercropping treatments. There were three additional treatments: two nitrogen levels applied to sole maize and one sole bean treatment.

The Land Equivalent Ratio - LER is considered to be one of the most appropriate indices to evaluate the efficiency of intercropping system in producing better yields as compared with yields in sole cropping (Willey, 1985). The index was used to assess maizebean intercropping advantages relative to sole cropping. Calculation of individual LER for maize considered yields of sole and intercropping systems at the same $\mathrm{N}$ level. The plant population of intercropped maize at M2 was similar to the plant population of sole cropped maize. For bean, calculation included a single sole cropping without nitrogen fertilizer.

The analysis of variance for maize at the final harvest combined the twelve factorial intercropping treatments and the two nitrogen levels applied to sole maize. A probability of $5 \%$ or less $(p<0.05)$ of significance was considered to differentiate effects among treatments according to the Last Significant Difference (LSD) test.

\section{RESULTS AND DISCUSSION}

Total dry matter accumulation per plant of maize in intercropping was not different from sole cropping in early stages of growth (Ofori \& Stern, 1986). Variation on patterns of dry matter accumulation of intercropped maize due to bean population was marginal, with no consistent tendency after 33 DAS. Dry matter accumulation in all intercropped maize treatments increased with application of N2 (Table 1). Patterns for dry matter accumulation of intercropped maize show that effects of increasing maize plant population from M1 to M2 were very small given that number of plants at M2 was double of that at M1.

Competitive effect of maize at M1 and M2 on total dry matter accumulation of intercropped beans was similar in all three-bean populations at both nitrogen fertilizer levels until 43 DAS (Table 2). After this time, individual bean plant growth improved at M1 and was always higher than at M2 in all situations, mainly at 53 and $63 \mathrm{DAS}$. The highest maize plant population brought about greater competition for natural resources, i.e. light, water and nutrients, therefore dry matter accumulation of individual bean plant was lower than at M1. Tsubo et al. (2003) confirm these findings and show that the ratio of decreases in dry matter accumulation of intercropping increases throughout the season as compared to sole cropping.

Total biomass yield of intercropped maize per unit area tended to increase with increasing maize population from M1 to M2 (Table 3). Application of nitrogen increased dry matter yield per plant of intercropped maize at $\mathrm{M} 2$ in $\mathrm{B} 1$ and $\mathrm{B} 2$, and only in B3 at M1, as compared with N1 (Table 4). It seems

Table 1 - Dry matter of maize at two plant populations (M1, M2) intercropped with beans at three plant populations (B1, B2, B3) under two nitrogen levels (N1, N2).

\begin{tabular}{|c|c|c|c|c|c|c|c|c|c|c|c|c|}
\hline \multirow{2}{*}{$\operatorname{DAS}^{(1)}$} & \multicolumn{3}{|c|}{ M1 N1 } & \multicolumn{3}{|c|}{ M2 N1 } & \multicolumn{3}{|c|}{ M1 N2 } & \multicolumn{3}{|c|}{ M2 N2 } \\
\hline & B1 & B2 & B3 & B1 & B2 & B3 & B1 & B2 & B3 & B1 & B2 & B3 \\
\hline & - & 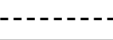 & & & & $\mathrm{g} \mathrm{pe}$ & ant $\ldots$ & 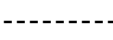 & & & & \\
\hline 23 & 6.40 & 4.50 & 6.40 & 5.21 & 4.11 & 6.79 & 5.86 & 7.10 & 7.08 & 6.03 & 6.55 & 6.20 \\
\hline 33 & 30.15 & 28.95 & 30.12 & 18.02 & 15.15 & 20.65 & 24.69 & 21.99 & 32.10 & 23.94 & 18.67 & 27.94 \\
\hline 43 & 78.29 & 65.36 & 45.72 & 35.60 & 34.38 & 62.10 & 59.29 & 61.38 & 75.58 & 59.27 & 61.40 & 60.38 \\
\hline $53^{(2)}$ & 149.99 & 121.80 & 117.69 & 76.69 & 94.83 & 104.64 & 121.06 & 126.29 & 147.95 & 123.30 & 138.53 & 122.74 \\
\hline 63 & 132.22 & 157.00 & 133.87 & 121.87 & 148.67 & 154.33 & 197.67 & 159.11 & 150.67 & 152.56 & 163.00 & 110.67 \\
\hline
\end{tabular}

${ }^{(1)}$ Days after sowing. ${ }^{(2)}$ Differences between numbers for maize population less than 18.8 and for bean population less than 23.0 are not different according to LSD test $(p<0.05)$. 
Table 2 - Dry matter of beans under three plant populations (B1, B2, B3) intercropped with maize at two plant populations (M1, M2) under two nitrogen levels (N1, N2).

\begin{tabular}{|c|c|c|c|c|c|c|c|c|c|c|c|c|}
\hline \multirow{2}{*}{$\mathrm{DAS}^{(1)}$} & \multicolumn{2}{|c|}{ B1 N1 } & \multicolumn{2}{|c|}{ B1 N2 } & \multicolumn{2}{|c|}{ B2 N1 } & \multicolumn{2}{|c|}{ B2 N2 } & \multicolumn{2}{|c|}{ B3 N1 } & \multicolumn{2}{|c|}{ B3 N2 } \\
\hline & M1 & M2 & M1 & M2 & M1 & M2 & M1 & M2 & M1 & M2 & M1 & M2 \\
\hline & $-\cdots$ & $\cdots$ & $\cdots$ & - & 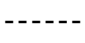 & per 1 & $t$-.- & - & -- & $\cdots$ & $\cdots$ & ----- \\
\hline 23 & 2.11 & 2.34 & 2.02 & 2.10 & 1.99 & 1.69 & 1.74 & 1.85 & 1.79 & 1.82 & 1.52 & 1.96 \\
\hline 33 & 2.47 & 2.49 & 3.35 & 2.17 & 4.08 & 2.13 & 2.43 & 4.34 & 2.38 & 2.81 & 2.92 & 2.65 \\
\hline 43 & 5.50 & 5.83 & 5.98 & 5.79 & 3.97 & 4.49 & 4.82 & 4.93 & 2.98 & 6.84 & 4.41 & 3.93 \\
\hline $53(2)$ & 10.74 & 4.05 & 9.21 & 6.76 & 11.80 & 5.86 & 11.06 & 6.15 & 7.09 & 5.78 & 9.70 & 7.67 \\
\hline 63(3) & 10.02 & 5.88 & 15.69 & 8.34 & 14.03 & 8.71 & 11.30 & 9.43 & 10.17 & 6.67 & 9.41 & 5.32 \\
\hline
\end{tabular}

${ }^{(1)}$ Days after sowing. Differences between numbers for maize population, at the same bean population and $\mathrm{N}$ level, less than ${ }^{(2)} 2.3$ and

(3) 2.6 are not different according to LSD test $(p<0.05)$.

Table 3 - Biomass, grain yield and harvest index of maize under different cropping systems and nitrogen levels $\mathbf{s}^{(1)}$.

\begin{tabular}{|c|c|c|c|c|c|c|c|c|c|c|c|c|}
\hline \multirow{3}{*}{$\begin{array}{l}\text { Cropping } \\
\text { System }^{(2)}\end{array}$} & \multicolumn{4}{|c|}{ Biomass yield $^{(3)}$} & \multicolumn{4}{|c|}{ Grain yield $^{(4)}$} & \multicolumn{4}{|c|}{ Harvest index ${ }^{(5)}$} \\
\hline & \multicolumn{2}{|c|}{ N1 } & \multicolumn{2}{|c|}{$\mathrm{N} 2$} & \multicolumn{2}{|c|}{$\mathrm{N} 1$} & \multicolumn{2}{|c|}{$\mathrm{N} 2$} & \multicolumn{2}{|c|}{ N1 } & \multicolumn{2}{|c|}{$\mathrm{N} 2$} \\
\hline & M1 & M2 & M1 & M2 & M1 & M2 & M1 & M2 & M1 & M2 & M1 & M2 \\
\hline & $-\cdots$ & (-.-- & (-...- & $\ldots-\ldots$ & $I^{-1}-\ldots$ & $\cdots$ & - & (-.-- & $-\cdots$ & $-\cdots$ & $-\cdots$ & $-\cdots$ \\
\hline \multicolumn{13}{|l|}{ Intercropping } \\
\hline $\mathrm{B} 1$ & 7527 & 10148 & 7187 & 12717 & 3175 & 4603 & 2951 & 5512 & 42.3 & 45.0 & 40.7 & 43.3 \\
\hline B2 & 8618 & 9469 & 8446 & 13958 & 3781 & 4593 & 3557 & 6195 & 43.3 & 48.7 & 42.0 & 45.0 \\
\hline B3 & 7516 & 11921 & 8508 & 12030 & 3181 & 5628 & 3408 & 5448 & 42.7 & 47.0 & 39.7 & 45.3 \\
\hline Mean & 7887 & 10513 & 8047 & 12902 & 3379 & 4941 & 3305 & 5718 & 42.8 & 46.9 & 40.8 & 44.4 \\
\hline Sole cropping & & 10248 & & 13122 & & 4937 & & 6157 & & 48.0 & & 46.7 \\
\hline
\end{tabular}

${ }^{(1)} \mathrm{N} 1, \mathrm{~N} 2$ are 0 and $30 \mathrm{~kg} \mathrm{~N} \mathrm{ha}^{-1}$, and M1, M2 are plant populations 1 and 2 for intercropped maize, respectively. ${ }^{(2)} \mathrm{B} 1, \mathrm{~B} 2, \mathrm{~B} 3$ are plant populations 1, 2 and 3 of intercropped beans, respectively. Differences between numbers for ${ }^{(3)}$ cropping system, maize population and $\mathrm{N}$ level less than 2345, 957 and 957, respectively. ${ }^{(4)}$ cropping system, cropping system $\times \mathrm{N}$ level interaction less than 1028 and 839 , respectively, and ${ }^{(5)}$ cropping system, maize population and $\mathrm{N}$ level less than 5.3, 2.1 and 2.1, respectively, are not different according to LSD test $(p<0.05)$.

Table 4 - Yield attributes of maize grown under different cropping systems and nitrogen levels ${ }^{(1)}$.

\begin{tabular}{|c|c|c|c|c|c|c|c|c|c|c|c|c|c|c|c|c|}
\hline \multirow{3}{*}{$\begin{array}{l}\text { Cropping } \\
\text { System }^{(2)}\end{array}$} & \multicolumn{4}{|c|}{ Dry matter per plant ${ }^{(3)}$} & \multicolumn{4}{|c|}{ Grain weight per plant ${ }^{(4)}$} & \multicolumn{4}{|c|}{ Cob per plant ${ }^{(5)}$} & \multicolumn{4}{|c|}{ Weight per $\operatorname{cob}^{(6)}$} \\
\hline & \multicolumn{2}{|c|}{$\mathrm{N} 1$} & \multicolumn{2}{|c|}{$\mathrm{N} 2$} & \multicolumn{2}{|c|}{$\mathrm{N} 1$} & \multicolumn{2}{|c|}{$\mathrm{N} 2$} & \multicolumn{2}{|c|}{$\mathrm{N} 1$} & \multicolumn{2}{|c|}{$\mathrm{N} 2$} & \multicolumn{2}{|c|}{$\mathrm{N} 1$} & \multicolumn{2}{|c|}{$\mathrm{N} 2$} \\
\hline & M1 & M2 & M1 & M2 & M1 & M2 & M1 & M2 & M1 & M2 & M1 & M2 & M1 & M2 & M1 & M2 \\
\hline & \multicolumn{8}{|c|}{ - } & & & & & \multicolumn{4}{|c|}{ 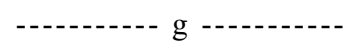 } \\
\hline \multicolumn{17}{|l|}{ Intercropping } \\
\hline B1 & 341.5 & 241.9 & 340.4 & 307.5 & 144.2 & 109.7 & 139.7 & 133.2 & 1.14 & 0.98 & 1.11 & 0.99 & 155.7 & 139.9 & 160.0 & 168.4 \\
\hline B2 & 404.8 & 234.9 & 418.1 & 337.5 & 157.1 & 114.0 & 176.3 & 149.7 & 1.28 & 1.03 & 1.38 & 1.07 & 169.0 & 136.5 & 161.7 & 176.7 \\
\hline B3 & 338.5 & 290.4 & 396.9 & 290.8 & 143.3 & 137.2 & 158.1 & 131.7 & 1.07 & 1.11 & 1.24 & 0.98 & 169.2 & 152.0 & 162.2 & 168.5 \\
\hline Sole cropping & \multicolumn{2}{|c|}{252.9} & \multicolumn{2}{|c|}{321.2} & \multicolumn{2}{|c|}{121.9} & \multicolumn{2}{|c|}{150.4} & \multicolumn{2}{|c|}{1.03} & \multicolumn{2}{|c|}{1.08} & \multicolumn{2}{|c|}{150.0} & \multicolumn{2}{|c|}{177.4} \\
\hline
\end{tabular}

${ }^{(1)} \mathrm{N} 1, \mathrm{~N} 2$ are 0 and $30 \mathrm{~kg} \mathrm{~N} \mathrm{ha}^{-1}$, and M1, M2 are plant populations 1 and 2 for intercropped maize, respectively. ${ }^{(2)} \mathrm{B} 1, \mathrm{~B} 2$, B3 are plant populations 1, 2 and 3 of intercropped beans, respectively. Differences between numbers for ${ }^{(3)}$ cropping system, maize population and $\mathrm{N}$ level less than 66.4, 14.7 and 14.7, respectively, ${ }^{(4)}$ cropping system, maize population and bean population less than $27.4,11.2$ and 13.7 , respectively, ${ }^{(5)}$ cropping system, maize population and bean population less than $0.17,0.07$ and 0.09 , respectively, and ${ }^{(6)} \mathrm{N}$ level less than 11.4 are not different according to LSD test $(p<0.05)$.

that bean plants at B1and B2 were not competing for available soil nitrogen in a high degree at M1, as compared with B3.

Raising bean population from B1 to B2 increased total biomass yield of intercropped maize at
M1 by $14 \%$ and $17 \%$ at $\mathrm{N} 1$ and $\mathrm{N} 2$, respectively. On the other hand, the increase for B3, compared to B1 at $\mathrm{N} 2$, corresponded to $18 \%$. Total biomass yield in $\mathrm{M} 2$ at N1 was $17 \%$ higher in B3 than with B1, being similar to N2 situation (Table 3). This implies that 
maize plants might have had more nitrogen available to absorb when intercropped with beans at higher populations.

Total biomass yield of sole maize at M2 and with fertilizer was higher than under intercropping at M1 in all situations (Table 3). Maize at M2, with the application of nitrogen and intercropped with beans at B2 showed total biomass yield significantly higher than and similar to sole cropping at $\mathrm{N} 1$ and $\mathrm{N} 2$, respectively. Nitrogen fertilizer improved total biomass yield of sole maize (Table 3).

Dry matter yield per plant at M1 was higher in all intercropping situations as compared with M2 (Table 4). The higher maize population increased grain yield per unit area of intercropped maize (Table 3 ). The increase, averaged over bean population, was higher at N2 (73\%) than at N1 (46\%). Cardoso et al. (1993) reported an increase of $37 \%$ in grain yield for the same rate of plant population in a maize-cowpea intercropping under irrigation condition. Grain yield per plant was significantly higher in M1 than in M2 (Table 4). This suggests an intra-specific competition for natural resources among intercropped maize plants at a higher population. Grain yield per unit area of intercropped maize tend to increase as bean population was increased from B1 to B2 (Table 3). This is attributed to increases in grain yield and number of cobs per plant (Table 4).

The main yield components for the increase in grain yield per unit area, due to application of nitrogen, were grain yield and number of cobs per plant (Table 4). Intercropping decreased grain yield of maize at M1, compared with sole cropping. The rates of reduction for mean over bean population were $32 \%$ and $46 \%$ at N1 and N2, respectively (Table 3). Similarly, Silwana \& Lucas (2002) showed a decreasing intercropping effect on maize yield of $34 \%$ when maize at
20,000 plants ha was intercropped with beans at 100,000 plants $\mathrm{ha}^{-1}$, as compared to sole maize at 40,000 plants $\mathrm{ha}^{-1}$. At M2, grain yield of intercropped maize was not much different from sole cropping at similar nitrogen levels, but the highest yield, obtained at B2-N2, was higher than the yield for sole cropped maize at N1. This is in agreement with early findings by Francis et al. (1978) for a maize-bean intercropping, where maize grain yields did not differ between sole and intercropping systems at a constant maize population.

Grain yield per unit area of intercropped beans decreased as maize population increased from M1 to M2 (Mutungamiri et al., 2001) in all bean populations at $\mathrm{N} 2$ and in B2 at N1 (Table 5). Decreases were caused by reduction on number of pods per plant. Increases in bean population increased grain yield per unit area of intercropped beans, mainly at N2 in B2 and B3 at both maize populations, as compared with B1. Nitrogen applied to maize rows tended to increase intercropped beans grain yield per unit area at M1, especially in B2 and B3. Number of pods per plant was the yield component most responsible for the increase (Table 5). It seems that beans probably benefited from the $\mathrm{N}$ applied to maize rows as the plants got closer to maize rows in B2 (1:2) and B3 (1:3) (Siame et al., 1997; Morgado \& Willey, 2003).

Harvest index of intercropped maize increased in all three-bean populations at both nitrogen levels as the maize population increased from M1 to M2 (Table 3 ), showing that the rate of increases due to increasing maize population was higher in grain yield than in total biomass yield. This effect was different in temperate climate under rainfed conditions, where maize harvest indices decreased with increase in maize population above optimum (Morgado \& Willey 2003). Harvest index of intercropped maize tended to decrease

Table 5 - Seed yield and yield attributes of beans grown under different cropping systems and nitrogen levels ${ }^{(1)}$.

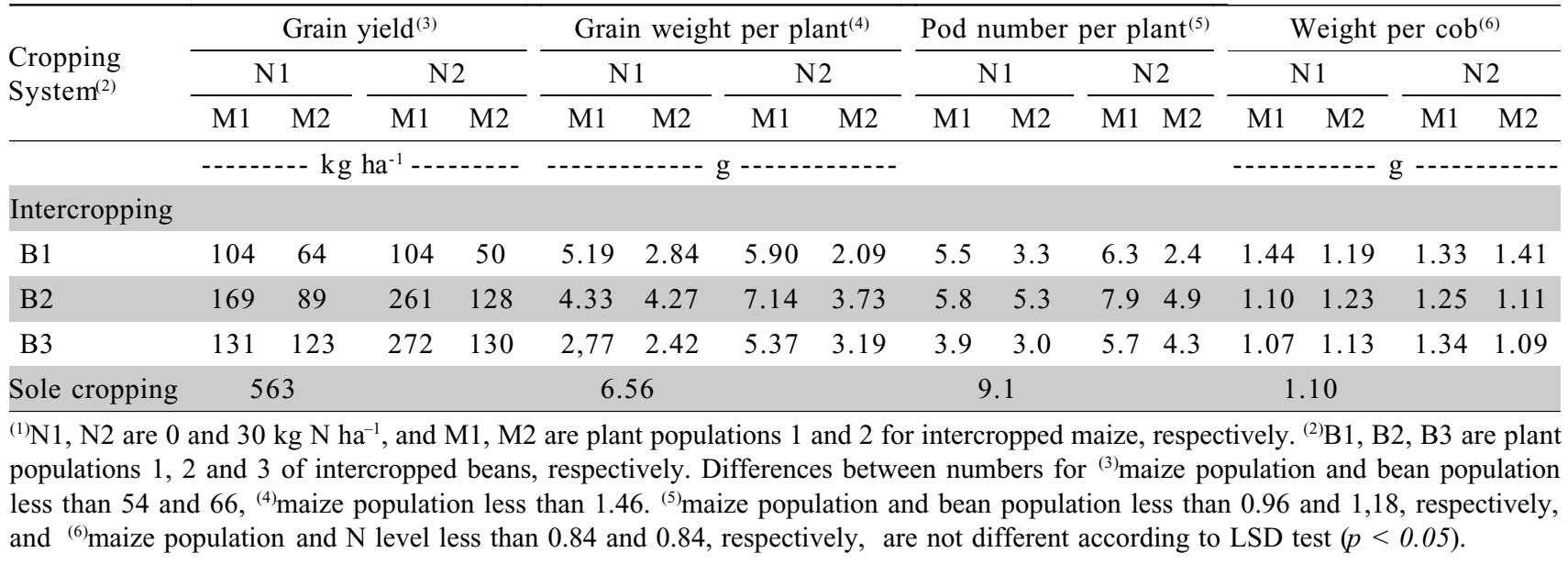


Table 6 - Land Equivalent Ratio for grain yield of maize and bean intercrops and total grain yield.

\begin{tabular}{|c|c|c|c|c|c|c|c|c|c|c|c|c|}
\hline \multirow{3}{*}{$\begin{array}{l}\text { Bean } \\
\text { population }\end{array}$} & \multicolumn{6}{|c|}{ Maize population 1} & \multicolumn{6}{|c|}{ Maize population 2} \\
\hline & \multicolumn{3}{|c|}{$0 \mathrm{~kg} \mathrm{~N} \mathrm{ha-1}$} & \multicolumn{3}{|c|}{$30 \mathrm{~kg} \mathrm{~N} \mathrm{ha}{ }^{-1}$} & \multicolumn{3}{|c|}{$0 \mathrm{~kg} \mathrm{~N} \mathrm{ha}^{-1}$} & \multicolumn{3}{|c|}{$30 \mathrm{~kg} \mathrm{~N} \mathrm{ha}^{-1}$} \\
\hline & Maize $^{(1)}$ & Beans $^{(2)}$ & Total $^{(3)}$ & Maize $^{(1)}$ & Beans $^{(2)}$ & Total $^{(3)}$ & Maize $^{(1)}$ & Beans $^{(2)}$ & Total $^{(3)}$ & Maize $^{(1)}$ & Beans $^{(2)}$ & Total $^{(3)}$ \\
\hline B1 & 0.66 & 0.26 & 0.90 & 0.48 & 0.37 & 0.85 & 0.96 & 0.11 & 1.07 & 0.90 & 0.13 & 1.03 \\
\hline B2 & 0.76 & 0.56 & 1.28 & 0.58 & 0.60 & 1.18 & 0.94 & 0.28 & 1.22 & 1.01 & 0.63 & 1.64 \\
\hline B3 & 0.66 & 0.27 & 0.93 & 0.55 & 0.59 & 1.14 & 1.16 & 0.28 & 1.34 & 0.89 & 0.33 & 1.22 \\
\hline
\end{tabular}

Differences between numbers for ${ }^{(1)}$ maize population, at same $\mathrm{N}$ level, and for $\mathrm{N}$ level, at same maize population, less than 0.12 , ${ }^{(2)}$ bean population, at same maize population and $\mathrm{N}$ level, less than 0.21 and ${ }^{(3)}$ bean population, at same maize population and $\mathrm{N}$ level, less than 0.28 are not different according to LSD test $(p<0.05)$.

with nitrogen application in all bean populations at M2, and in B3 at M1 (Table 3). Intercropping tended to decrease harvest index of maize, being lower at M1 in all the situations, except for B2 - N1, as compared with sole cropping at N1.

Harvest index of maize was higher in sole than in intercropping (Oljaca et al., 2000) but declined as nitrogen fertilizer was applied (Table 3). Maize LERs were higher at M2 than at M1 in all three-bean populations at both nitrogen fertilizer situations, because of a greater competition by higher maize population (Table 6). Application of nitrogen tended to decrease maize LERs in both maize populations (Ofori \& Stern, 1987). This effect was significant at M1 in all bean populations and at M2 in B3. The lower maize LERs under nitrogen fertilizer condition were brought about by higher increases in grain yield of sole cropping as compared with the increases in intercropping. Maize LERs tended to increase with increasing bean populations, and in B3 maize LER for M2 at N1 was 16\% (LER = $1.16)$ higher than in sole cropping (LER $=1.00)$. Maize plants possibly made a better use of soil resources, i.e. water and nutrients, when intercropped with beans at $\mathrm{B} 2$ and $\mathrm{B} 3$.

Bean LERs increased with increases in bean population at M1 in all situations, except in $\mathrm{B} 3$ at N1, and at M2 only in B2 with nitrogen application. Nitrogen fertilizer tended to increase bean LERs. Increases were more evident at $\mathrm{B} 2$ and $\mathrm{B} 3$ where the bean plants were closer to maize rows. This might be attributed to the fact that bean plants possibly benefited from the nitrogen applied to maize rows (Siame et al., 1997; Morgado \& Willey, 2003). Increasing maize population from M1 to M2 decreased bean LERs. This effect was greatest at B1.

Total LERs tended to increase with increasing bean populations due to higher bean LERs and to increases in maize LERs, mainly at M1 in all situations, except in B3 at N1 level and at M2 in B2 with application of N2. Nitrogen fertilizer increased total LERs in B2 at M2 and B3 at M1. The highest total LERs at M1, 1.28 and 1.18, were obtained with B2 at N1 and N2, respectively. Both maize and bean components were higher at B2 than at B1 and B3, suggesting that maize and beans at that situation had an optimum balanced plant population and could make a better use of natural resources. At M2, the highest total LER (1.64) with nitrogen fertilizer application was also obtained in B2. For the no nitrogen-applied situation, the highest total LER (1.34) was obtained in the highest bean population (B3) where maize component had the highest LER (1.16).

As a conclusion, intercropping is more productive than sole cropping and advantage as high as $28 \%$ and $64 \%$, were obtained at M1 and M2 respectively.

\section{REFERENCES}

CARDOSO, M.J.; FREIRE FILHO, F.R.; RIBEIRO, V.Q.; FROTA, A.B.; MELO, F.B. Densidade de plantas no consórcio milho $x$ caupi sob irrigação. Pesquisa Agropecuária Brasileira, v.28, p.93-99, 1993.

CARDOSO, M.J.; FREIRE FILHO, F.R.; RIBEIRO, V.Q.; FROTA, A.B.; MELO, F.B. Arranjo populacional no consórcio milho $\mathrm{x}$ feijão macassar (Vigna unguiculata (L.) Walp.) em regime de sequeiro. Revista Ceres, v.41, p.19-27, 1994.

CHOWDHURY, M.K.; ROSARIO, E.L. Comparison of nitrogen, phosphorus and potassium utilization efficiency in maize/ mungbean intercropping. Journal of Agricultural Science, v.122, p.193-199, 1994.

FARIS, M.A.; BURITY, H.A.; REIS, O.V.; MAFRA, R.C. Intercropping sorghum or maize with cowpea or common beans under two fertility regimes in the Northeast Brazil. Experimental Agriculture, v.19, p.251-261, 1983.

FRANCIS, C.A.; FLOR, C.A.; PRAGUE, M. Effects of bean association on yields and yield components of maize. Crop Science, v.18, p.760-764, 1978.

LIMA, A.F.; LOPES, L.H.O. Plant population and spatial arrangement study on the intercropping of maize and beans (Phaseolus vulgaris L.) in Northeast Brazil. In: INTERNATIONAL WORKSHOP ON INTERCROPPING, Patancheru, 1979. Proceedings. Patancheru: ICRISAT, 1981. p. 41-45.

MAFRA, R.C.; LIRA, M.A.; ARCOVERDE, A.S.S.; LIMA, G.R.; FARIS, M.A.O. O consórcio de sorgo e milho com os feijões de arranca e macassar no Nordeste do Brasil. Pesquisa Agropecuária Pernambucana, v.3, p.93-104, 1979.

MORGADO, L.B. Estudo sobre densidade de plantio de sorgo e feijão-caupi consorciados no semi-árido brasileiro. Revista Ciência Agronômica, v.37, p.357-363, 2006. 
MORGADO, L.B.; WILLEY, R.W. Effect of plant population and nitrogen fertilizer on yield and efficiency of maize-bean intercropping. Pesquisa Agropecuária Brasileira, v.38, p.1257-1264, 2003.

MUTUNGAMIRI, A.; MARIGA, I.K.; CHIVINGE, A.O. Evaluation of maize (Zea mays L.) cultivars and density for dryland maizebean intercropping. Tropical Agriculture, v.78, p.8-12, 2001.

OFORI, F.; STERN, W.R. Maize/cowpea intercrop system: effect of nitrogen fertilizer on productivity and efficiency. Field Crops Research, v.14, p.247-261, 1986.

OFORI, F.; STERN, W.R. The combined effect of nitrogen fertilizer and density of legume component on production efficiency in a maize/cowpea intercropping system. Field Crops Research, v.16, p.43-52, 1987.

OLJACA, S.; CVETKOVIC, R.; KOVACEVIC, D.; VASIC, G.; MOMIROVIC, N. Effect of plant arrangement pattern and irrigation on efficiency of maize (Zea mays) and bean (Phaseolus vulgaris) intercropping system. Journal of Agricultural Science, v.135, p.261-270, 2000.

RAO, M.R.; MORGADO, L.B. A review of maize-beans and maizecowpea intercropping systems in the semi-arid Northeast Brazil. Pesquisa Agropecuária Brasileira, v.19, p.179-192, 1984.

RUSSELL, J.T.; CALDWELL, R.M. Effect of component densities and nitrogen fertilization on efficiency and yield of maize/ soyabean intercrop. Experimental Agriculture, v. 25, p.529540,1989
SIAME, J.; WILLEY, R.W.; MORSE, S. A study of the partitioning of applied nitrogen between maize and beans in intercropping. Experimental Agriculture, v.33, p.35-41, 1997

SILWANA, T.T.; LUCAS, E. O. The effect of planting combinations and weeding on the growth and yield of component crops of maize/bean and maize/pumpkin intercrops. Journal of Agricultural Science, v.138, p.193-200, 2002.

TRENBATH, B.R. Resource use by intercrops. In: FRANCIS, C.A. (Ed.) Multiple cropping systems. New York: Macmillan, 1986. chap.4, p.57-81.

TSUBO, M.; MUKHALA, E.; OGINDO, H.O.; WALKER, S. Productivity of maize-bean intercropping in a semi-arid region of South Africa. Water SA, v.29, p.381-388, 2003.

WILLEY, R.W. Intercropping: its importance and research needs. Part 1. Competition and yield advantages. Field Crops Research, v.32, p.1-10, 1979.

WILLEY, R.W. Evaluation and presentation of intercropping advantages. Experimental Agriculture, v.21, p.119-133, 1985 .

Received September 12, 2006

Accepted April 11, 2008 